University of Nebraska - Lincoln

DigitalCommons@University of Nebraska - Lincoln

Faculty Publications, Department of History

History, Department of

2002

\title{
The Special Operations Executive (SOE) in Austria, 1940-1945
}

Gerald Steinacher

University of Nebraska-Lincoln, gsteinacher2@unl.edu

Follow this and additional works at: https://digitalcommons.unl.edu/historyfacpub

Part of the European History Commons, and the Military History Commons

Steinacher, Gerald, "The Special Operations Executive (SOE) in Austria, 1940-1945" (2002). Faculty Publications, Department of History. 140.

https://digitalcommons.unl.edu/historyfacpub/140

This Article is brought to you for free and open access by the History, Department of at DigitalCommons@University of Nebraska - Lincoln. It has been accepted for inclusion in Faculty Publications, Department of History by an authorized administrator of DigitalCommons@University of Nebraska - Lincoln. 


\section{The Special Operations Executive (SOE) in Austria, 1940-1945}

\section{Gerald Steinacher}

"Passive grumbling, rather than resistance" ${ }^{1}$

In January 1941, Great Britain's Special Operations Executive (SOE) defined its policy on Austria with two objectives: (1) to assist in the disintegration of the Third Reich by fostering the soon to be expected all-out revolutionary and separatist uprising in Austria; and (2) to bring about the "restoration of Austria as a national unit" within the framework of a central European federation. In short, the hopes and aspirations of the SOE in the Austrian resistance against Nazi Germany were flying high. ${ }^{2}$ Five years later, in March 1946, Britain's political representative in Vienna, William B. Mack, summarized the history of the Austrian resistance for Foreign Secretary Ernest Bevin. Already the first phrases of Mack's report made clear that there was hardly any history to tell: “The Austrian Resistance Movement cannot bear comparison with similar organizations in other countries occupied by the German Army during the war nor, with the possible exception of the Communist-sponsored Austrian Freedom Front (O.F.F.) and the all-party 'O5' Organization, did any section of it make any significant contribution to the Allied victory."3

Now, with the SOE files on Austria partially released, the history of the Austrian resistance can be written, at least from the British perspective, ranging from high expectations at the beginning to disillusion at the end. What were the SOE plans and actions on promoting Austrian resistance and what was finally achieved? ${ }^{4}$ 


\section{Responding to the Nazi Invasion}

When German troops entered Austria on the morning of 12 March 1938 they found no resistance. In all major towns large crowds of Austrians welcomed the Wehrmacht as liberators. As a consequence, the country became an integral part of the Third Reich. With only Mexico protesting, the international powers accepted the development on the grounds of British "appeasement policy" with Adolf Hitler. Austria should cease to exist forever-or should it?

Britain's reaction to the vanishing of the Republic of Austria was not protest but secret action. With the feeling that there was more to come from Hitler, Prime Minister Winston Churchill ordered a new section of the Secret Intelligence Service (SIS)-Section D-which was to become the Special Operations Executive (SOE). Never really happy about the Anschluss, Churchill saw Austria as a wartime tool that could be used to weaken Germany and reorder Central Europe. For Churchill, Austria was among the countries for whom Great Britain took the sword. His Foreign Minister, Anthony Eden, made the unspecified British position clear in January 1942: The Anschluss was not formally repudiated, nor was Austria considered an occupied country. ${ }^{5}$ Emphasis was placed on the liberation of Austria from Nazi rule, not on an independent Austria. ${ }^{6}$ The SIS headquarters in Vienna was soon neutralized when Station Chief Captain Thomas Kendrick was arrested by the Gestapo in August 1938. George Berry, the new Station Chief, had insufficient time before the outbreak of the war to organize an efficient network of agents to remain in occupied Austria. ${ }^{7}$

The plan for Austria did not restart before January 1941, when the SOE defined its policy on Austria with two objectives. The first was to assist in the disintegration of the Third Reich by fostering the soon-to-be-expected revolutionary and separatist uprising in Austria, fully supported by propagandist, political, and military action. The principal organizations to be contacted for this aim were the Social Democrats, the Catholics, and the Monarchists. To prepare ground for the imminent uprising against the Germans, the Social Democrats and Catholics would be contacted and supported via the SOE's ample channels in Yugoslavia, and the Monarchists through Hungary. A special elite corps of saboteurs, paratroopers, and leaders would be sent into the country "twenty-four hours before the crack comes." Single acts of sabotage or partisan movements were strictly condemned. ${ }^{8}$ This concept of "secret armies" was formulated in 1940-1941 by SOE director Major Colin Gubbins for all European countries; Austria was to be no exception. ${ }^{9}$ Britain's high expectations were partly based on the fact that the SOE planners on Austria saw the Anschluss as a result of the efficiency of the German military and political apparatus. For this reason, according to the SOE, there was no possibility of resistance or bloodshed. A fait accompli was achieved within a matter of hours. 
The second, obviously less important aim was "the restoration of Austria as a national unit." Austria would be divided into provinces. Exiled Austrians would be selected for key positions within the country for "the decisive moment." But the SOE plan contained no details on Austrian borders or political systems. ${ }^{10}$ In fact, the SOE took over from Britain's vague foreign policy. All groups of Austrian resistance, from the extreme right to the extreme left, would be contacted and supported for antiGerman action. Therefore, getting in touch with Austrian politicians, both those in exile and those still in Austria, was deemed most important. ${ }^{11}$ Consequently, the SOE contacted Austrian organizations in London. In 1941- 1942, these consisted a wide range of small and smaller organizations, such as the Communist-sponsored Free Austria Movement, the Association of Austrian Social Democrats, Austria Office, Austrian Academy, and the Austrian Centre, among others. ${ }^{12}$ A bitterly divided group, no single organization could be representative of overall opinion in Austria. The Foreign Office therefore advised the SOE to "limit such informal contacts as prove essential to the bare minimum." The SOE could not discuss any questions of foreign policy, and there could be no encouraging of a central Austrian representation of any kind in Great Britain. ${ }^{13}$

\section{The Austrian Psyche}

In January 1943, Britain's Foreign Office summed up the "Opinion and Morale in Austria," outlining chances of resistance based on SOE sources. Austria remained a separate country, despite the similarity between Austria and southern Germany. This could not be changed by the Anschluss. On the contrary, the feeling of "Austrians being different from Germans" grew even stronger. The "boom" immediately after the Anschluss vanished rapidly, and in 1941 doubt grew as to whether the Anschluss was justified at the price of war.

The following factors contributed to bring about this change of mind: Austrians thought that the war was primarily the Germans'. The news of casualties had a bad effect on morale. Dislike of German and Prussian prapotence in the land, and the large numbers of refugees from the Reich, disappointed Austrian Nazis, who achieved far lower positions than they had hoped for. Goebbels's propaganda against the Russian Asiatic hordes showed effect in Austria as in Germany. The strong religious sentiments of the peasantry were affronted by anti-Catholic measures. The Austrians longed for nothing so much as the end of the war. In addition, there was less fear of the consequences of defeat in Austria than there was in Germany, but also no agreement as to what the future of Austria should be. The Anschluss wish was dead, but an open dislike of the Nazi regime provided very little evidence that Austrians anywhere were prepared to make violent uprisings for the sake of their freedom. ${ }^{14}$ This would be changed by encouraging Austrian patriots. 
But how could this be achieved? At this stage, the most important SOE informant on Austria was Sir George Franckenstein, the former Austrian ambassador to Britain. Franckenstein contributed his views and suggestions to the making of general British policy on Austria: Great Britain should take the initiative with regard to the Austrian question, he said, otherwise "Austria could land in the Russian net." 15 He pleaded for a declaration from the Allies concerning Austria's liberation and independence. This, he stated, was the only way to develop Austrian resistance and to contribute to the Allied war efforts. Due to their key positions, he urged that Austrians should have been central in encouraging and leading sabotage, revolts, and removal of Austrian units in the Wehrmacht. ${ }^{16}$

\section{The Road To Independence}

The turning point in Allied foreign policy on Austria came on 1 November 1943, when the Allies affirmed in the Moscow Declaration that Austria, as the first victim of Hitler's aggression, should regain its independence after the war ended. But in reminding Austria of its own responsibility in the war, the Allies stated that they would take into account what the Austrians would themselves do for their liberation. Now that clear policy on Austria's future had been formulated for the first time, ${ }^{17}$ this declaration was intended to stir up Austrian resistance against Hitler. Not until after the Moscow Declaration did Allied post-war planning on Austria begin on a broader scale. Massive BBC radio propaganda for the country did not actually begin until November 1943 in reaction to this declaration. ${ }^{18}$

Because the SOE was still "comparatively ignorant of conditions inside Austria" at that time, it decided to do everything to increase secret intelligence from the country, however difficult it might be. ${ }^{19}$ Without doubt, this document really backed Austrian patriots at a time when many considered the Anschluss as sealed by the Allies. Yet, to a good extent, members of the Austrian Resistance Movement could not achieve active military resistance to the Germans. Theirs could be better defined as passive resistance: the wearing of Austrian national colors and the use of the familiar and typical Austrian greeting "Grüß Gott” (God be with you) instead of "Heil Hitler." As a Foreign Office official put it, this constituted "passive grumbling rather than resistance." 20

\section{SOE's Learning Process}

At the SOE's London headquarters, Austrian affairs were dealt with in the German division, directed by Ronald Thornley. Like Thornley himself, most of the 
personnel were trained for Germany, not for Austria. Peter Wilkinson, who was given the German and Austrian Division to supervise, wrote: "I found this embarrassing, for I knew very little about Germany and nothing whatever about Austria, which I had only once visited as a tourist." ${ }^{21}$ Lacking most of the SOE files on Austria may have been a principal reason for the relative ignorance of the Austrian situation. By the end of 1943, there were two main centers for SOE activities on Austria: the small Central European Division in Monopoli in southern Italy (where the "Clowder missions" directed by Wilkinson are best known), and the Austro-German Division in the SOE's Bern outpost in neutral Switzerland, directed by H. I. "Bill" Matthey. "Clowder" began in late July 1944. One early report on these activities stated: "It is just pure bad luck, and our star will doubtless change soon, but there is no denying the fact that, after five months of toil, we still have no agents inside Austria." 22

"Clowder" saw only the southern parts of the Austrian province of Carinthia as a realistic base for penetrating Austria. The Slovenian-speaking population living mainly along the Austrian-Slovenian border had already been organized by Josip Broz (Tito) into a few partisan bands. From there, the plan was to penetrate the Austrian heartland. ${ }^{23}$ But the beginning of 1945 brought total disillusionment. "Clowder" did not consider that the Allies would be able to make "any declaration sufficiently attractive to the Austrians to persuade them to embark on a policy of open resistance, or to help us to any significant extent." A widespread resistance movement was not to be expected before the total defeat of Germany.

The SOE position was later taken over by the director of the Foreign Office's Central European department. Declarations and propaganda were not expected to encourage Austrian resistance to any larger degree: "All that can be hoped for is a small degree of sabotage and possibly one or two coups-de-main." 24 This assumption on Austrian resistance finally proved to be correct. The SOE missions sent to Carinthia soon realized that the Austrian Slovenians in southern Carinthia (partially organized as the "Austrian Freedom Front" or OFF) had little or no interest in liberating Austria, but more in occupying the territory claimed by Yugoslavia. ${ }^{25}$

The activity of SOE parties in southern Carinthia, consisting partially of Germanspeaking Austrians, was soon to be made impossible. In southern Austria, the Slovenian partisan movement was weak due to German raids. By the end of 1944, it had no organized connections to the resistance in central Austria. The SOE thus concluded that the penetration of Austria should become independent of the Titosponsored partisan movement in the outermost areas of southern Austria. ${ }^{26} \mathrm{Al}-$ though "Clowder" sent in a good number of SOE missions to Carinthia, it never achieved this goa1. ${ }^{27}$ Foreign Secretary Bevin was informed that "they were almost entirely composed of Austrian Slovenes, and until the last few days of the war ... they 
never fired a shot on Austrian soil." ${ }^{28}$ Peter Wilkinson gave two reasons for the failure of "Clowder": first, there was no strong will for resistance up to the very last days of the war in Austria; and second, the SOE had underestimated both the seriousness and the consequences of Tito's territorial claims in Austria. ${ }^{29}$

\section{The Resistance Movement}

The director of the German-Austrian Division of the SOE in Bern, Switzerland, was Squadron Leader H. I. Matthey. As he took over office in September 1944, he was introduced to the leader of "Patria," the Austrian Monarchist resistance movement, which was based in Switzerland. Matthey was convinced that if there was any chance of Catholic resistance, the "Patria" organization would develop it. As a consequence, Matthey became more concerned with Austria than with Germany.

Patria enabled the SOE to send its first missions into western Austria. The helping hand of the discrete Swiss secret service was vital for these missions. The first reports showed how difficult the work was, as well as how apathetic the Austrian population was. Missions to the Austrian population in the Italian border province of Bolzano (South Tyrol) showed more promise. In January, the Bern SOE office, with the help of Patria, contacted a resistance group under the leadership of Hans Egarter (his alias was "Barbarossa") comprising as many as 600 men scattered in the valleys of the province. Everything possible was done to stimulate its activities. An Allied WIT operator, weapons, and money were sent in. The group had its headquarters in a liberated valley, executed some acts of sabotage, infiltrated German police regiments, and defended themselves against German mop-ups. Its activity was stimulated by one political aim: The annexation of the province to a new Republic of Austria. "Barbarossa" met John McCaffery once in Bern to discuss these territorial claims. In this way, they tried to influence Britain's post-war territorial settlements

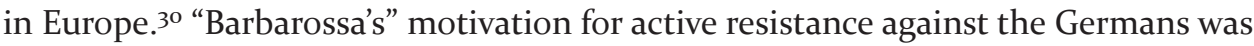
to show the Allies that their cause was also the cause of the Austrian minority in Italy. The "Patria" and "Barbarossa" organizations in the province of Bolzano were the only productive contacts Matthey ever handled. ${ }^{31}$ In August 1945, he made this fact clear when he wrote:

It must always be matter for regret that [the Patria] did not get in touch with us a year or more earlier, since there is no doubt that, given a little more time, we might easily have got Barbarossa's lot properly organized and from his group we might have slowly built up a network of smaller efficient groups in Austria. But the gods willed it otherwise, so we must content ourselves with the knowledge that there was at least one Austrian who got within measurable distance of effectively resisting the Nazis. ${ }^{32}$ 


\section{Comparing The Movements}

The parallels between the assumptions of "Clowder" and the SOE in Bern are obvious. Both found resistance only in connection with territorial conflicts. The Siovenian partisan groups in southern Austria fought for the annexation of their area to Yugoslavia, while the Austrian resistance groups in the Italian province of Bolzano were motivated by the possible return of their homeland to Austria. Neither plan could be realized. They showed, however, the importance of territorial aims in Central Europe in motivating resistance, and how they were underestimated or misunderstood by the SOE.

The resistance group in the heartland of Austria best known to the United States and its wartime secret service, the Office of Strategic Services (OSS), was "O5." Though nonpartisan, it was dominated by the middle classes. With headquarters in Vienna, $\mathrm{O}_{5}$ claimed supporters throughout the country, but apart from the group in Innsbruck, it did not amount to much. In March 1945, the SOE reported for the first time on the group $\mathrm{O}_{5}$, based on OSS reports. The SOE took a very pessimistic view of the $\mathrm{O}_{5}$ 's claims to organize widespread resistance in Austria. As the SOE realized, the OSS seemed miles ahead in establishing connections with $\mathrm{O}_{5}$, so the SOE decided to align with the OSS and stated that it "should pull up our socks." 33 The first SOE reports about $\mathrm{O}_{5}$ in April were still quite sceptical, because $\mathrm{O}_{5}$ 's claims contained "a great deal of wishful thinking." $34 \mathrm{O}_{5}$ 's plans to assist in the liberation of Vienna could not be realized because leaders of the Viennese resistance group were caught and executed by the German SS. The Foreign Office-SOE Committee stated in consequence "that there was very little evidence to show that the Viennese had assisted their liberation in any way." 35 Only Innsbruck was liberated by $\mathrm{O}_{5}$ groups under the leadership of the late Foreign Minister Karl Gruber. The British political representative in Vienna later informed Foreign Secretary Bevin about Gruber's resistance:

In Western Austria the main group ... seems to have been vaguely subordinated to $\mathrm{O}_{5}$... Its claim to have occupied Innsbruck before the arrival of American troops is to some extent vitiated by the fact that the German Army Group SouthWest, which included the Tyrol in its command, had already signed the Armistice at the time. This did, however, have the result that Dr. Gruber, the leader of the Resistance in the Tyrol and the present Foreign Minister, was able to form a provisional government in that province, where the Resistance Movement continued to maintain a considerable influence on political affairs up to the time of its official dissolution in December 1945. With the single exception of Tyrol, the Resistance Movement had exercised almost as little political influence since the end of hostilities as it did military influence before it. ${ }^{36}$ 


\section{Unanswered Questions}

Austrian Resistance was almost entirely passive: no open armed resistance, no partisan movement, and no leader of note produced (with the exception of Gruber). The attempt to stir up resistance by declarations promising independence and better treatment in exchange for resistance against the Third Reich proved to be a failure.

In recognizing this fact, three questions present themselves for further research:

1. On which assumptions were SOE plans up to 1943, expecting widespread open resistance in Austria, based?

2. What were the differences between SOE plans for Austria and Germany?

3. Why did the SOE miscalculate the importance of territorial and ethnic conflicts in Central Europe? These misinterpretations finally led to the failure of the main SOE centers of Austrian resistance: "Clowder" and the SOE office in Bern.

\section{References}

${ }^{1}$ Günter Bischof, "Anglo-amerikanische Planungen und Überlegungen der österreichischen Emigration während des Zweiten Weltkrieges für Nachkriegs-Österreich" in Manfried, Rauchensteiner and Wolfgang Etschmann (eds.), Österreich 1945, Ein Ende und viele Anfänge (Vienna: 1977), p. 32.

${ }^{2}$ Austrian division of the SOE, Memoranda on Austria, 21 January 1941. Public Record Office (PRO), HS 6 (SOE Western Europe), 3 (Policy of Austrian Division).

3 William B. Mack, British political representative in Vienna to Ernest Bevin, 7 March 1946. PRO, FO 1049 (Control Commission for Germany, SHAEF political office) 540 (Austrian situation).

${ }_{4}$ Compared to the secondary literature on the U.S. intelligence involvement in Austria, scholarly works on the role and impact of British intelligence in Austria have been quite scarce. Subjects covered include the attempts by the SOE to penetrate into southern Austria in 1944--45 with the help of the Tito Partisans, SIS/SOE activities in Southern Tyrol in 1944--45, and the security work of the British military Field Security Section (FSS) in Styria. Cf. Thomas M. Barker, Social Revolutionaries and Secret Agents: The Carinthian Slovene Partisans and Britain's Special Operations Executive (Boulder, CO: 1990); Peter Wilkinson, Foreign Fields: The Story of an SOE Operative (London: I.B. Tauris, 1997); Gerald Steinacher: "At least one Austrian effectively resisting the Nazis ... Allied secret services and the making of Austrian resistance myths on the eve of the Cold War" in Christopher An- 
drew (ed.), Intelligence and National Security (forthcoming); and Felix Schneider, "Zur Tiitigkeit des miliärischen Geheimdienstes FSS und des Public Safety Branch in Graz 1945-1947" in Graz 1945 (Historisches Jahrbuch der Stadt Graz 25) (Graz: 1994), pp. 215-233. See also Siegfried Beer, "Von Alfred Redl zum Dritten Mann. Österreich und ÖsterreicherInnen im internationalen Geheimdienstgeschehen 1918-1947." Geschichte und Gegenwart 16 (1997), pp. 3-23.

5 Anthony Eden to the British embassy in Washington, 28 September 1942. (CONFIDENTIAL). PRO, HS 6 (SOE, Western Europe), 3 (Policy of Austrian section). "Foreign Office Directive for Austrian Broadcasts," 20 February 1942. PRO, Foreign Office (FO) 898 (Political Warfare Executive), 216 (German Division).

6 “Foreign Office Directive for Austrian Broadcasts." PRO, FO 898/216.

7 Beer, "Von Alfred Redl zum Dritten Mann. Osterreich und OsterreicherInnen im internationalen Geheimdienstgeschehen 1918-1947" in Geschichte und Gegemrart 16 (1997), p. 16. The importance of Vienna for intelligence activities before and after the war is well known. Kim Philby, Peter Smollet (Peter Smolka), and Arnold Deutsch all started their NK VD careers in the Austrian capital. See Christopher Andrew and Vasili Mitrokhin, The Mitrokhin Archive: The KGB in Europe and the West (London: Penguin, 1999).

${ }^{8}$ Austrian division of the SOE, Memoranda on Austria, 21 January 1941. PRO, HS 6 (SOE Western Europe), 3 (Policy of Austrian Division).

9 David Stafford, Britain and European Resistance 1940-1945: A Survey of the Special Operations Executive with Documents (London: Macmillan, 1980), p. 31.

${ }^{10}$ Austrian division of the SOE, Memoranda on Austria, 21 January 1941. PRO, HS 6 (SOE Western Europe), 3 (Policy of Austrian Division).

11 "Short analysis of the Austrian emigration in G.B." 1942. HS 6 (SOE, Western Europe), 2 (Austria).

${ }^{12}$ List of Austrian Organizations in London, 1940. PRO, HS6 (SOE, Western Europe), 4 (Austria).

${ }^{13}$ Geoffrey W. Harrison to SOE in London, 11 March 1942. PRO, HS 6 (SOE, Western Europe), 2 (Free Austrian movement).

14 "Opinion and Morale in Austria." Memoranda of Foreign Office, German Division based on SOE material. 25 January 1943. (CONFIDENTIAL). PRO, HS 6 (SOE, Western Europe), 3 (Policy of Austrian Division).

15 Sir George Franckenstein to SOE in London, 16 May 1943 (VERY CONFIDENTIAL, SECRET). “Comments on Sir George Franckenstein's letter to S.O.” Notiz, 19 April 1943, Letter SOE in London, and Franckenstein 16 April 1943, some handwritten notes. PRO, HS 6 (SOE, Western Europe), 4 (Use of political groups and freedom movements for SOE activities; Sir George F ranckenstein).

${ }^{16}$ Sir George Franckenstein, and SOE in London 14 March 1943. HS 6 (SOE, Western 
Europe), 4 (Use of political groups and freedom movements for SOE activities; Sir George Franckenstein).

17 The significance and the meaning of the Moscow Declaration are still controversial among historians. The traditional school emphasizes this document as a declaration of the independence of Austria, which as a state became "the first victim of Hitler's aggression." In response to this "victim-myth," some researchers interpret the Moscow Declaration as merely part of the Allies' psychological warfare. For the first school of thought, see Gerald Stourzh, Geschichte des Staatsvertrages 1945-1955. Österreichs Weg zur Neutralität (Graz: Styria, 1985). For the revisionist point of view, read Robert Keyserlingk, Austria in World War II: An Anglo-American Dilemma (Kingston: Queens University Press, 1988) and Günter Bischof, "Die Instrumentaiisierung der Moskauer Erklärung nach dem Zweiten Weltkrieg" in Zeitgeschichte 20 (1993), Heft 11/12, pp. 354-366.

${ }^{18}$ Notes on BBC Programs to Austria, 25 November 1943, PRO, FO/898/216.

19 Austrian Editor of BBC to SOE London, November 1943. PRO, FO/898/216.

${ }^{20}$ Günter Bischof, "Anglo-amerikanische Planungen und Überlegungen der österreichischen Emigration." p. 32 ff.

${ }^{21}$ Peter Wilkinson, Foreign Fields: The Story of an SOE Operative (London: I.B. Tauris, 1997), p. 126.

22 "Report for period 2nd July--19th July 1944, TO:X, From: XA/2." 19 July 1944 (TOP SECRET). PRO, HS 6 (SOE Western Europe), 18 (Austria, Maryland mission).

23 “Report on Clowder Mission.” 13 May 1945. (TOP SECRET). PRO, HS 6 (SOE, Western Europe), 17 (Clowder).

${ }^{24}$ Notice Geoffrey W. Harrisons for Mr. Mack and others, 18 March 1945 (SECRET). PRO, FO 371 (General Correspondence/Allied Commission for Austria), 46603 (Austrian frontier).

25 "Memorandum by H.Q. Clowder Mission on Future of Special Operations in Austria.” 16 January 1945. (TOP SECRET). PRO, HS 6 (SOE, Western Europe), 17 (Clowder).

26 "Report on a mission to Carinthia (Korosko) May to September 1944." November 1944. (TOP SECRET). PRO, HS 6 (SOE, Western Europe), 17 (Clowder).

27 There were 28 SOE missions to Austria, most of them between February and the end of April 1945. Eighteen missions were sent from "Maryland," and 10 from the SOE HQ in Bern.

${ }^{28}$ William B. Mack, British representative in Vienna, to Ernest Bevin, 7 March 1946. PRO, FO 1049 (Control Commission for Germany, SHAEF political office) 540 (Austrian situation).

29 Peter Wilkinson, Foreign Fields, p. 156 ff. 
$3^{30}$ Letter of the former SOE agent Christopher Woods to the author, 29 November 1997.

${ }^{31}$ Report of H. I. Matthey, "General History from September 1944 to July 1945," and "Part II. History of Black activities." 30 August 1945. Foreign Office, SOE Archive, copy in possession of the author.

${ }^{2}$ Report of H. I. Matthey "Part II. History of Black activities," 30 August 1945. Foreign Office, SOE Archive, copy in possession of the author.

33 Telegram to SOE London, 31 March 1945. PRO, HS 6 (SOE, Western Europe), 20 (Maryland).

34 Telegram from SOE in London to SOE in "Maryland” (Brindisi), 1 April 1945. PRO, HS 6 (SOE, Western Europe), 20 (Maryland).

35 Provisional Minutes of the Meeting of the Foreign Office-SOE Committee, 17 April 1945. (TOP SECRET). PRO, FO 371/46603 (Austrian Frontier).

${ }^{36}$ William B. Mack. British representative in Vienna to Ernest Bevin. 7 March 1946. $\mathrm{PRO}, \mathrm{FO} / \mathrm{Io} 49 / 540$. ANO 